\title{
O LÉXICO REAL
}

\author{
The Royal Lexicon
}

Jean Pierre CHAUVIN ${ }^{9}$

Resumo | Neste artigo, examinam-se pressupostos, teor e objetivos da carta régia assinada por Dom João de Bragança, na Bahia, em 28 de janeiro de 1808, à luz da aliança política e teológica vigente no Reino de Portugal, sob o viés da intricada administração reinol e a antiga relação comercial da Coroa portuguesa com a Inglaterra. $\mathrm{Na}$ análise dos textos, mediante resgate de sua legibilidade original, examina-se o léxico utilizado pelos remetentes, de modo a averiguar sua relação com a mentalidade reinol e reforça a autoridade real, em convergência com os pressupostos da Igreja Católica.

Palavras-chave | Abertura dos Portos. Carta Régia. Léxico. Representação.
Abstract | In this article, we examine the assumptions, the content and the objectives of Dom João de Bragança's royal charter, which was written in Bahia on January 28, 1808, in the light of the political and theological alliance in the Kingdom of Portugal, under the intricate royal administration and the old trade relationship between the Portuguese Crown and England. In the analysis of the texts, we intend to rescue their original readability in a way to demonstrate if the lexicon used by senders was related to the royal mentality. This reinforces the king's authority, in convergence with the premises of the Catholic Church.

Keywords | Ports Opening. Royal Charter. Lexicon. Representation. 
- | O léxico real

"[...] no príncipe nada brilha com fulgor mais intenso que a fé reta" (Doutor Frei Serafim de Freitas, 1625).

"Nenhuma pessoa poderá vestir-se de pano que não seja fabricado neste Reino" (Pragmática de 1677).

"[...] para a Inglaterra, o direito de estabelecer com o Brasil relações de soberano e de vassalo" (Lord Strangford, em 1807).

\section{Motivação}

A carta régia enviada pelo príncipe regente ${ }^{10}$ Dom João de Bragança" ao Conde da Ponte, quando um e outro se encontravam na Capitania da Bahia, em 28 de janeiro de 1808, tem sido objeto de cuidadosa discussão por parte de historiadores, que veem no documento a confirmação oficial (ou "real") de que o jugo da Inglaterra, mais evidente a partir do século XVIII, chegara ao ápice. Em 1925, Max Fleuiss (1925, p. 66) supusera que:

A abertura dos portos foi uma consequência lógica dos fatos: emigrada a Corte para o Brasil em 1808, não mais se faria possível ficarem os portos brasileiros trancados ao livre-câmbio pela simples razão de que, encontrando-se Portugal em poder da França, seria estulto conservar privilégios e monopólios, de que só haveria de auferir lucros o inimigo invasor; e precisando a Monarquia, mais do que nunca, de avolumar suas fontes de receita, já que o ouro das minas escasseava cada vez mais e paralisado o comércio de navegação com os portos do Reino, fechados pelo inimigo a Portugal, o único expediente indicado era mesmo a livre franquia dos portos, a exploração da indústria e comércio livres com as nações amigas

Em que pese algum ufanismo do historiador - que enxergava o Brasil como nação, antes mesmo da transferência político-administrativa da Coroa portuguesa para o território ${ }^{12}$-, a forma como seleciona e historiciza os eventos induz-nos a estabelecer relações diretas entre o esgotamento das minas auríferas e a decisão real de migrar para a sua gigantesca possessão americana.

10 “D. João, embora administrando o Reino desde fevereiro de 1792, só tomou o título de Príncipe Regente em julho de 1799" (MARTINS FILHO, 1968, p. 21, grifo do autor).

11 “Segundo filho de d. Maria I, foi d. João, por falecimento de d. José I, em 1788, com 21 anos completos, reconhecido herdeiro presuntivo do trono, sob o título de príncipe do Brasil" (FLEUISS, 1925, p. 62).

12 Esse nó conceitual já foi desfeito por diversos historiadores, a exemplo de Evaldo Cabral de Mello: "O brasileiro dos estratos superiores percebia-se como o súdito de um Estado que não pretendia encarnar uma nação inexistente, mas o velho sonho luso-brasileiro de 'um grande Império' na América, projeto que já se esboça nos primeiros cronistas e que D. João VI viera declaradamente estabelecer. Àquela altura, os nacionalistas não éramos nós, mas os portugueses de Portugal que, dentro e fora das Cortes de Lisboa, clamavam contra o que lhes parecia a escandalosa inversão de papéis pela qual o Brasil transformara-se no centro da monarquia lusitana, relegando a própria metrópole à condição de colônia" (MELLO, 2002, p. 15). 
Fator levado em maior conta era a antiga aliança entre Portugal e Inglaterra ${ }^{13}$, que foi decisiva na grandiosa operação preparada com meses de antecedência - antes do embarque da Corte em 29 de novembro de 1807. Como anota Rodrigo Ricupero (2011, p. 116):

A situação de Portugal como aliado e protegido da Inglaterra é que tornou possível e quase imperativa a causa decisiva da singularidade do processo brasileiro de independência: a transferência da Corte ao Brasil sob a proteção da esquadra inglesa, viabilizando um futuro e eventual processo controlado de transição à independência.

Do ponto de vista econômico, a abertura dos portos "às nações amigas" representou, quase de imediato, o câmbio comercial mais favorável aos estrangeiros do que ao reino português. As implicações políticas eram evidentes. A carta também constituía sinal de gratidão (e compromisso), firmado entre Portugal e Inglaterra, antes mesmo da partida da esquadra lusitana, rumo à Bahia, em novembro de $1807^{14}$

Esse comprometimento do Reino português com a Inglaterra teria sido firmado, oficialmente, com um mês de antecedência à viagem realizada em direção ao Estado do Brasil. Ressalte-se, porém, que a carta - datada de 22 de outubro de 1807 -, não havia brotado espontaneamente. Fora precedida pelo diálogo secreto entre as cortes, afinado em 27 e 30 de agosto daquele ano. ${ }^{15}$

No artigo VII do documento, assinalado como "Convenção Secreta entre o Príncipe Dom João e Jorge III, Rei da Grã-Bretanha", lê-se o seguinte: "Quando o Governo Português estiver estabelecido no Brasil proceder-se-á a negociação de um Tratado de auxílio e de comércio entre o Governo Português e a Grã-Bretanha" (MENDONÇA, 1984, p. 23).

Antes de o conselheiro Dom Rodrigo de Sousa Coutinho ter se pronunciado a respeito do fechamento dos portos e transferência da Corte para o Brasil, "O representante diplomático inglês em Lisboa, Strangford, comunicava a Canning, a 20 de agosto de 1807,

13 “[...] durante a maior parte do período até 1770, [...] a importância de Portugal e do Brasil para o comércio inglês e para a economia inglesa em geral foi não apenas marcante, mas cada vez mais considerável" (FISHER, 1984, p. 24-25).

14 "Mais tarde o almirante da esquadra britânica, sir Sidney Smith e o cônsul inglês sir James Gambier obtiveram uma sobretaxa de trânsito de $4 \%$ à taxa única que era indistintamente cobrada, quer se destinassem às mercadorias a consumo no próprio local, quer à reexportação, extinguindo-se assim a uniformidade de taxa" (FLEUISS, 1925, p. 67).

15 Em 27 de agosto de 1807, Dom Rodrigo de Sousa, Conde de Linhares, observa ao Príncipe Regente as consequências relativas ao fechamento dos portos. Na carta seguinte, de 30 de agosto, o Conselho de Estado português delibera sobre a necessidade de que a Corte seja transferida para o Brasil (Cf. MENDONÇA, 1984, p. 10-17). 
um plano segundo o qual Portugal concederia aos ingleses o direito de estabelecerem casas comerciais no Brasil e mesmo de exportarem tecidos de algodão para os domínios portugueses" (SILVA, 2010, p. 298).

Alan Manchester (1973, p. 75) observou, com razão, que "A abertura dos portos ao comércio mundial significava na realidade que, em relação à Europa, os portos estavam abertos apenas ao comércio da Inglaterra, enquanto durasse a guerra no continente". Cumpre lembrar que, muito antes de assinado o Tratado de Methuen (1703) ${ }^{16}$, a parceria entre os reinos de Portugal e Inglaterra havia sido acionada em termos mais explícitos. Por ocasião do centenário da transferência da Corte para o Rio de Janeiro, Manuel de Oliveira Lima (1980, p. 7-8) assinalou que:

Também a influência britânica em Portugal constituía uma feição adquirida e já peculiar da política peninsular, datando o seu início no tempo das pelejas continentais dos reis de Inglaterra pelos tronos de França, quando Dom João, o Mestre de Aviz, desposou Dona Filipa de Lancastre. É muito sabido que sob os Braganças, durante o reinado de Dom Pedro II, essa influência, que tomara vigor com o enlace de Dona Catarina, filha de Dom João IV, com Carlos II de Inglaterra e a consequente cessão de Tanger e Bombaim, revelou-se decisivamente no tratado comercial chamado de Methuen.

De acordo com José Hermano Saraiva (2005, p. 273):

O primeiro ato de descolonização econômica foi o decreto de 28 de janeiro de 1808, que abriu os portos brasileiros aos navios estrangeiros em condições de igualdade com os portugueses e permitiu a importação de mercadorias de todas as procedências. Esta medida foi tomada a pedido dos comerciantes da Bahia, quando o príncipe regente ali passou, a caminho do Rio, mas representava o cumprimento de compromissos assumidos para com a Inglaterra, que havia feito essa exigência durante as negociações de 1807.

A maior parte dos acordos comerciais previam a troca de conveniências, em que a proteção externa das águas e fronteiras territoriais de Portugal tinha como contraparte

16 "O interesse da Inglaterra no país foi maior no período de 1654 - quando os interesses dos mercadores e da frota comercial britânicos transformaram Portugal praticamente num vassalo comercial da Inglaterra - até 1825 [data de reconhecimento por parte de Portugal], quando a colônia do Brasil conquistou sua independência" (MANCHESTER, 1973, p. 17). Conforme argumenta Carlos Guilherme Mota, "Pelo Tratado de Methuen de 1703 com a Inglaterra, Portugal enredara-se nas malhas do nascente imperialismo britânico, processo que tanto dom Luís da Cunha quanto o futuro marquês de Pombal perceberam quando embaixadores em Londres. De fato, o Tratado de Methuen foi celebrado na sequência dos tratados de 1654 e 1660 e no bojo da Guerra de Sucessão espanhola (1701-1713), guerra mundial com repercussões no mundo colonial, inclusive no Brasil, com o ataque de franceses ao Rio de Janeiro (Duguay-Trouin à frente), inimigos que eram da Inglaterra" (MOTA, 2007, p. 76). 
o favorecimento comercial inglês ${ }^{17}$. A esse respeito, Fernando Novais (1989, p. 19-20) assinalou que:

Aaliança inglesa tinha raízes antigas, em Portugal, remontando mesmo à primeira dinastia. Com a ascensão de Aviz, o tratado de Windsor (1386) consolidou as boas relações, prevendo favores comerciais recíprocos e dispondo sobre a mútua defesa. Mas é sobretudo no quadro de tensões que se seguem à Restauração de 1640, com a prolongada guerra para manter a independência recobrada, que a presença inglesa assume a forma característica que domina no século seguinte: a troca de aliança e mesmo proteção política por vantagens comerciais crescentes. ${ }^{18}$

A vinda da extensa Corte portuguesa para o Estado do Brasil, em fuga às tropas comandadas por Junot, reafirmou, de um lado, o comportamento ambivalente dos lusitanos que, simultaneamente, despistaram os franceses e protelaram, ao máximo, a decisão de solicitar apoio aos ingleses (de maneira a escapar em direção a sua maior possessão ultramarina). A viagem, sob proteção inglesa, ratificou a dependência econômica, política e naval daquele reino em relação aos britânicos. Veja-se, por exemplo, o parecer do Marquês de Belas, assinado em 2 de novembro de 1807:

Tudo o mais são consequências destes princípios: é necessário tratar com sinceridade com os amigos e inimigos, declarados ou encobertos, principalmente quando são superiores em forças. Uma certa franqueza, sendo discreta, vale mais nestes casos, que a política mais refinada, se acaso não o é esta, que consiste enganar com a verdade (MARTINS FILHO, 1968, p. 56).

No mesmo dia, o Visconde de Anadia evidencia o caráter ambivalente das ações adotadas pelos portugueses, com o intuito de retardar o avanço das tropas francesas:

\footnotetext{
17 "A Corte inglesa exigiu a entrega da ilha da Madeira para servir de base naval, compensando a perda dos portos lusos, o que foi concedido às pressas. Em fins de setembro, finalmente, foram delegados poderes ao representante luso em Londres, Sousa Coutinho, para negociar a convenção secreta que presidiria as relações entre Inglaterra e Portugal, até assinatura de tratado efetivo. A convenção foi firmada a 22 de outubro de 1807: é a origem dos acordos de 1810" (SODRÉ, 1969, p. 122-123).

18 De acordo com Nelson Werneck Sodré, "Portugal encontrava-se, depois da Restauração, na dependência quase absoluta dos fornecimentos externos. Não só comprava utilidades como alimentos. Da Holanda, Inglaterra, França e Itália recebia manufaturas; e mandava-Ihes açúcar, tabaco, madeiras tintoriais, mais tarde ouro e pedras preciosas, produtos coloniais; do Reino, quase tão somente sal e vinhos. Devia, por isso mesmo, empregar todos os esforços no sentido de produzir uma parte pelo menos daquilo de que necessitava para a subsistência de sua gente. As primeiras manifestações nesse sentido traduziram-se nas pragmáticas. Eram estas leis reais destinadas a coibir o luxo" (SODRÉ, 1969, p. 24-25).
} 
- O léxico real

[...] é necessário, e urgente fazer suspender por todos os modos que ainda restam a entrada do exército combinado em Portugal, fazendo logo sair do Reino a agentes ingleses que ainda aqui se comprovam, suspender a partida de navios nacionais para os portos da Grã-Bretanha, declarar prisioneiros de guerra os ingleses que ainda aqui se acham, nas circunstâncias de poder sobre eles recair, segundo o novo direito atual da guerra, este comisso, e mandar pôr em depósito ${ }^{19}$ os seus bens, e se fazer logo partir tanto D. Lourenço, como o Embaixador Extraordinário com estas participações. Isto se deverá preterir com todas as formalidades, que façam rumor, declarando entretanto ao Ministro e Ministério inglês, que a dura lei da necessidade e de suprema reforma e salvação do Estado nos obrigou a este penoso procedimento público, mas que na realidade será restituído ocultamente e que se deixará o porto aberto aos indivíduos para que possam retirar-se com a aparência de fuga, a qual se lhes facilitará por todos os meios indiretos que se oferecerem (MARTINS FILHO, 1968, p. 64, grifos meus).

Evidentemente, a mudança na relação com o Estado do Brasil não seria pequena. Daí a razão de os conselheiros do Estado terem sido consultados com frequência muito maior, nos meses que antecederam a viagem da realeza. De acordo com Fernando Novais (1989, p. 298): "[...] a vinda da Corte para o Brasil marca a primeira ruptura definitiva do Antigo sistema. A abertura dos portos do Brasil, imposta pelas circunstâncias e decretada como provisória, seria na realidade irreversível". Por sua vez, Alan Manchester (1973, p. 78) apontava que:

Embora a imigração inglesa não tenha se materializado no Brasil, o comércio inglês com o país ganhou vida nova depois de 1808. Uma ordem publicada nos jornais de Londres, pelo Ministro português, exortava todos os comerciantes daquela cidade que pretendiam fazer negócios com o Brasil a se reunirem em 25 de junho para considerar os meios de melhorar seus lucros. Cento e treze comerciantes londrinos uniram-se à associação que foi organizada naquela data .

Cumprindo com o que fora acordado com os ingleses, em reuniões transcorridas meses antes do embarque da Corte, chegando a Salvador, o primeiro ato oficial do príncipe regente - o futuro Dom João VI de Portugal - foi expedir a carta endereçada ao Conde da Ponte, dias após a sua chegada na Bahia. O documento é sobremodo objetivo, mas as consequências foram enormes e nada tinham de provisório, como sugeria a carta.

19 Ou seja, sequestrar os bens em benefício do Estado português. 


\section{Palavra}

No examine da documentação a seguir, proceder-se-á ao levantamento do léxico empregado pelos signatários, tendo em vista reconstituir, dentro do possível, a legibilidade dos documentos (HANSEN, 1989), levando-se em conta as circunstâncias e o momento em que foram escritos.

A ideia é resgatar os protocolos de leitura com que as cartas e congêneres foram redigidas, tendo em vista os fins pretendidos pelo reino de Portugal, em sua dúbia relação com os ingleses e franceses. Para isso, foram transcritos excertos da intensa correspondência que circulou nas cortes europeias, no início do século XIX.

Como se disse, a carta régia não é o único registro da decisão adotada pela coroa portuguesa. Em parecer relativo a uma reunião promovida pelo reino, em agosto de 1807, o douto João de Almeida de Melo de Castro refere-se ao rei em termos condizentes com a posição do relator e o gênero de que se vale - o parecer - para refletir sobre a reunião conduzida dias antes pela Alteza Real:

Estas altas qualidades e virtudes que resplandecem e se admiram tanto na Augusta Pessoa de V. A. R. brilham com um novo esplendor na resolução verdadeiramente grande que $V$. A. R. tomou, certificando com a segurança das pessoas e bens dos vassalos britânicos que residem nos Estados que o Onipotente confiou a direção eu domínio de V. A. R. (MARTINS FILHO, 1968, p. 25).

O parecer não se referia exclusivamente às decisões tomadas em Conselho. Àquela altura, Napoleão aliara-se à Rússia, com o objetivo de impedir o comércio inglês por mar. ${ }^{20}$ Como observou Nelson Werneck Sodré (1969, p. 115):

Mal começara o ano de 1807 quando Napoleão, em poderosas e rápidas manobras, forçou os russos a aceitarem, com a derrota de Friedland, a sua política, de que era peça fundamental o bloqueio da Europa ao comércio inglês. Para concretizá-la, era necessário impedir o acesso dos ingleses aos portos continentais. E a área mais vulnerável à penetração britânica estava na península ibérica e particularmente no reino de Portugal, tradicional aliado inglês e país submetido à expansão comercial comandada de Londres (SODRÉ, 1969, p. 115).

\footnotetext{
20 Para uma perfeita compreensão do bloqueio francês em relação ao Brasil, convém lembrar que a Inglaterra mantinha então, não apenas a liderança da produção industrial, mas também a do fornecimento dos produtos coloniais de seu império; e desejava controlar a redistribuição da produção dos territórios ultramarinos portugueses, parte dela concorrente com a dos seus. Ora, metade das exportações lusas para o exterior era constituída de produtos brasileiros reexportados e $80 \%$ das exportações (em grande parte constituída de mercadorias inglesas) de Portugal para as Colônias, destinava-se ao Brasil (AGUIAR, 1960, p. 28).
} 
Na tentativa de prolongar a relação ambígua com a Inglaterra ${ }^{21}$ - o mais antigo aliado do Reino - Portugal protelava a tomada de decisões. Eis que no dia 24 de novembro ${ }^{22}$, às vésperas da viagem, o Conselho de Estado é convocado em caráter de urgência, para que os membros tomassem ciência dos termos apresentados pelos ingleses, como estes do Contra-Almirante: ${ }^{23}$

Sir Sidney Smith, Comandante da esquadra inglesa que bloqueia o porto desta Capital [...] anuncia o tratamento hostil que praticaria se as disposições de Portugal não fossem amigáveis, ameaçando com o estrito bloqueio, requisição dos navios de guerra portugueses e dos marcantes que navegam para o Brasil (MARTINS FILHO, 1968, p. 70).

A recomendação dos conselheiros é explícita: "se não devia perder um só instante em acelerar o embarque de S. A. R. o Príncipe Regente Nosso Senhor e de toda a Real Família para o Brasil" (MARTINS FILHO, 1968, p. 71). ${ }^{24}$ De todo modo, a fuga da Corte não constituiu mero atropelo que impedisse a consecução do plano mirabolante, mentalizado havia séculos, embora tivesse ganhado forma com a pressão, tanto dos franceses quanto dos ingleses. ${ }^{25}$

\footnotetext{
21 "Formalmente, Portugal passou a ficar em estado de guerra com duas potências inimigas entre si, a França e a Grã-Bretanha. Para o governo português, tratava-se de uma situação transitória, que teria como saída um rápido apaziguamento com a França, sustando a invasão iminente, dado que já se havia cedido a todas as exigências de Napoleão" (ALEXANDRE, 2007, p. 107).
}

22 "A 24 de Novembro, cinco dias após ter atravessado a fronteira, [Junot] atinge Abrantes. Parece que só no dia seguinte a notícia chega a Lisboa, trazida pelo tenente-coronel Leor, que se lança a cavalo, num galope doido, para comunicar a chegada iminente dos invasores. Que deve fazer o Príncipe Regente? Até aí, enquanto pôde, negociou e cedeu. Perante o atentado da partilha de Fontainebleau, que o general de Napoleão trata de efetivar, em marcha veloz pelo país afora - convoca o Conselho de Estado e unanimemente se resolve transferir a Corte para o Rio de Janeiro, capital do Portugal americano (AMEAL, 1942, p. 561).

23 “O tempo da diplomacia havia passado. As operações militares tiveram início no mesmo dia, 24 de novembro de 1807, quando os ingleses decretaram oficialmente o bloqueio do porto de Lisboa e as tropas francesas cruzaram a fronteira do Alentejo. Finalmente, no dia 29 de novembro, o Príncipe Regente embarcou rumo ao Brasil, levando consigo os 36 navios ambicionados por Napoleão, 18 de guerra e 25 mercantes, e neles a elite portuguesa, com todos os seus pertences, de valor e de estima" (ARRUDA, 2008, p. 37).

24 “Fracassadas as desesperadoras manobras para aplacar ou enganar Napoleão, inclusive a inacreditável proposta aos ingleses de uma guerra simulada, os governantes portugueses são obrigados a enfrentar dilacerante dilema: escolher entre a invasão do território ou a perda das colônias" (RICUPERO, 2011, p. 119).

25 “Se a saída de D. João VI para a América do Sul teve, em dado momento, a exclusiva aparência dum pânico liberativo, e se a atitude da Corte, embarcando numa esquadra, em trigosa debandada, dava ao quadro aspectos de fuga, de naufrágio ou de qualquer outra catástrofe, nem por isso é lícito concluir que se tratava de um ato impensado, indecoroso, pois é certo que o embarque da família real fora previsto com antecedência de muitos anos e refletido em todas as suas consequências" (NORTON, 2008, p. 24). A ressalva de Luís Norton, apoiada no volumoso estudo de Oliveira Lima (1908), foi corroborada por Érika Dias recentemente: "Pode-se dizer que muitas foram as vezes em que se pensou nesta retirada para o Brasil: sempre que a monarquia corria perigo, o Brasil era lembrado como refúgio ideal para o rei ou para membros da família real" (DIAS, 2010, p. 554). 
No que se refere à carta régia de Dom João de Bragança, afora os antigos protocolos de Cortesia ${ }^{26}$, respeitados em sua redação, o texto assinado manda que se executem as suas reais vontades, em cumprimento ao que estabelecera nas poucas linhas seguintes. Comecemos por lembrar que o documento trocado entre padres, militares, diplomatas, administradores e políticos recebia grande influxo da tradição.

Parece haver correspondências entre o teor e formalismo da documentação político-administrativa e o ambiente em que circulavam os Cortesãos, desde o século XVII. É o que sugere Eduardo d'Oliveira França (1997, p. 53):

O século XVII é por excelência o século do teatro. Do grande teatro. Se o teatro encontra uma apaixonada receptividade é porque ele corresponde à vaidade do tempo. Nele os homens se encontravam retratados ou caricaturados. [...] Esse amor pelo teatro [literário] era signo de uma peça teatral em que cada um representava o seu papel. Às vezes, depois de estudá-lo previamente. Época de tipos. Tipos que se estandardizavam. No vestuário. Nos gestos e atitudes e até na linguagem. ${ }^{27}$

De um lado, o aspecto formal a espelhar a rígida hierarquia portuguesa, lastreado por numerosas leis ${ }^{28}$ :

Com as adaptações necessárias, na América Portuguesa prevaleceu parte da legislação vigente no Reino. Desde 1603, o Código Filipino era a lei básica e geral implantada e a "legislação extravagante" visava legislar e dar suporte jurídico a realidades específicas que surgiam da expansão do Império. Despachava-se uma série de leis do centro político para outras áreas dos domínios portugueses; alvarás, cartas e ordens-régias tinham o objetivo de resolver impasses entre os interesses da política metropolitana e as demandas dos locais a que se dirigiam (SOUZA, 2016, p. 53).

26 O regimento "trazido por [Tomé de] Sousa, escrito em 1548, ainda do reinado de D. João III, representava o começo da construção de uma administração mais normatizada nas então ainda partes do Brasil. A opção de denominar os domínios portugueses na América de partes e não de Estado, nos dois primeiros regimentos [dos Governadores-Gerais] refletia o processo de construção de uma unidade política, ainda em fase inicial" (SANTOS, 2009, p. 119-120).

27 Um estudo mais detalhado das condições econômicas do Brasil nos fins do século XVIII, parece indicar, por exemplo, que a mineração, cujo ciclo histórico se encerrava naquela centúria pelo quase esgotamento das catas dos placers aluviônicos, criara, com as concentrações urbanas cuja formação estimulara, condições para a construção de uma estrutura de economia do mercado. (AGUIAR, 1960, p. 24).

28 “Por todo o século XVII era tão vasto e complexo o corpo de leis extravagantes, cartas régias, alvarás e provisões do Reino, cujos preceitos colidiam e se anulavam por vezes, que, ao ser enviado ao Brasil como governador, Roque da Costa Barreto, foi necessário escolher e condensar as melhores práticas no novo Regimento Geral, que lhe foi dado a 25 de Janeiro de 1677" (FLEUISS, 1925, p. 46). 
A seleção de palavras e o modo como elas eram dispostas no documento sugere que a carta assinada por Dom João de Bragança não admitiria espontaneidade ou arroubo de sentimentos. Homóloga, em relação aos procedimentos formais praticados na Corte, vários códigos se sobrepõem no universo Cortesão:

A "racionalidade" da Corte, se podemos chamar assim, não recebe o seu caráter específico, como a racionalidade científica, nem em função do esforço pelo conhecimento e controle de fenômenos naturais exteriores ao humano, nem em função do planejamento calculado da estratégia na concorrência pelo poder econômico, como a racionalidade burguesa. [...] seu caráter específico deriva, em primeiro lugar, do planejamento calculado da estratégia de comportamento em relação a possíveis perdas e ganhos de status e prestígio sob a pressão de uma competição contínua pelo poder (ELIAS, 2001, p. 110).

A carta sujeitava-se a regras estritas de composição, protocolos de endereçamento e publicização, também como sintoma de que, desde o tempo dos Filipes, "a escrita passou a ser muito utilizada como forma de dominar um império tão vasto" (SANTOS, 2009, p. 127). No que se refere especialmente à linguagem e estruturação do documento, tratava-se de gênero discursivo com séculos de existência. Ramo da arte Retórica, a Ars Dictaminis prescrevia - pelo menos desde o final da Idade Média - modos de datar, endereçar, narrar, solicitar e concluir.

Essas partes constam do breve documento assinado por Dom João. No manuscrito de 28 de janeiro de 1808, as primeiras quatro linhas compreendem a identificação e saudação do destinatário, Conde da Ponte, membro do "meu Conselho" e "Capitão General da Capitania da Bahia", "Amigo", "aquele que Amo".

A seguir, o príncipe alude às "críticas e públicas circunstâncias da Europa", para, finalmente, expor a sua real decisão, que encerra com a prescrição do que antes havia sido ordenado no reino, "ficando [...] em suspenso e sem vigor, todas as leis, cartas régias, ou outras ordens que até aqui proibiam neste Estado do Brasil o recíproco comércio e navegação entre os meus vassalos e estrangeiros".

Nas linhas finais, antes de antepor a sua assinatura, Dom João delega para o Conde da Ponte a implementação de seu "desejo", certo de que será excetuado com máximo "zelo", por seu subordinado local. Recorde-se que o Capitão Geral representava o poder máximo, na ausência do Rei. Sob esse aspecto, a carta régia de 28 de janeiro de 1808 também formaliza o que ordenava o reino, quando do fatiamento do território brasileiro, bem como a eleição e atribuições dos primeiros capitães donatários, em 1532. 
Àquela altura, a intenção da Coroa era registrar a real vontade do Príncipe Regente em reverter as ações constantes dos alvarás lavrados em 1591 e 1605, que versavam sobre a proibição do comércio estrangeiro nas colônias portuguesas, salvo mediante autorização concedida pelo rei: "Sou servido ordenar interina, e provisoriamente, [...] que não só os meus vassalos, mas também os sobreditos estrangeiros possam exportar para os Portos [o] que bem lhes parecer a benefício do comércio, e agricultura, que tanto desejo promover" (DOM JOÃO, 1808, p. 1).

No que se refere ao teor da carta, bem como aos termos e modo como que foi escrita, patenteia-se que, embora as consequências para Portugal fossem as mais severas, tratava-se de um documento escrito não sob o calor da hora, ou mediante inspiração divina, mas em atendimento ao acordo firmado com os ingleses, no ano precedente. Por isso, era destinada às "Potências, que se conservam em paz e harmonia com a minha Real coroa, ou em navios dos meus vassalos".

Porventura haja interesse em discutir o léxico empregado no documento. Ao proceder a análise, leve-se em conta o emprego recorrente de alguns vocábulos, por parte do príncipe regente, dentre os quais os pronomes possessivos ("meu", "minha"), o adjetivo "Real" e os substantivos "vassalo" e "vontade".

\section{Corpo}

Uma leitura de nosso tempo, pós-cartesiano, pós-saussureano e pós-moderno, sugeriria que a repetição dos pronomes pudesse ilustrar o caráter personalista de um jovem autoritário e que o uso de "real", com letra maiúscula, guardasse relação com a ideia de "verdade". Advirta-se, no entanto, que o uso desses e outros termos, nas correspondências régias, eram previstos e integravam a expectativa dos leitores. A repetição dos pronomes possessivos não se restringiria ao caráter supostamente individualizante de Dom João: o conceito de indivíduo sequer existia, na forma como o conhecemos e utilizamos hoje. Em verdade, a ênfase nos possessivos relembra uma das principais lições que o reino herdou da igreja católica.

Como mostrou Ernst Kantorowicz (1997), deve-se a Paulo de Tarso a tese de que a igreja era formada pela cabeça e pelos membros da instituição, em analogia com o corpo humano:

Essa fisionomia corporativa, característica dos primeiros séculos do Período Moderno português, começou a se configurar na segunda metade do século $\mathrm{XV}$, durante o reinado de D. João II. A reunião de poderes em torno dos monarcas portugueses fez com que eles passassem a personificar o reino na concepção própria do ordenamento corporativo. Assim, a tarefa de governar 
pertencia ao monarca e aos seus auxiliares, ministros, tribunais e conselhos. O rei era a cabeça do reino e comandava os membros e órgãos restantes (ministros, tribunais, conselhos) tidos como extensões do seu corpo, "órgãos", "ouvidos" e "mãos" (COSENTINO, 2009, p. 43).

Por ampliação semântica, dois corpos teria o reino: o temporal, representado pelo próprio rei; o espiritual, representado pelo papa - relacionado aos dogmas e questões que transcendiam o plano terreno. Institucionalmente, reino e papado atribuíam-se o papel de contrapartes de um mesmo organismo, a sugerir a poderosa analogia entre os membros constitutivos ("vassalos"), tendo por cabeça a coroa do reino (poder terreal) e a mitra (poder celestial). Daí a síntese de João Adolfo Hansen (1989, p. 68):

Unidade do corpo, pluralidade dos membros e diversidade das funções das várias partes são as três articulações com que Santo Tomás propõe o corpo, de modo que a integração de suas partes num todo harmônico é ordem: o pé é instrumento do olho, pois o leva de lugar a lugar; o olho, instrumento do pé, porque o guia em sua marcha [SANTO TOMÁS, 1957a, p. 210 e segs.]. Por analogia, o corpus hominis naturale é termo de comparação com o corpus Ecclesiae mysticum: é o termo caput (cabeça) que, basicamente, efetua a relação. Analogicamente, assim, as metáforas da cabeça e do corpo humano podem nomear as partes superior e inferior de outros corpos analógicos: referem-se à Igreja como corpus Christi, à sociedade como ordinata multitudo e, ao homem, ser natural, como corpus naturale [SANTO TOMÁS, 1952]...

Sob essa perspectiva, seria mais adequado considerarmos que a vontade do rei (ou do príncipe regente) simbolizava e encarnava o gesto de um estado, por sua vez atrelado aos desígnios supostamente transcendentais que aportavam do Vaticano. A referência à primeira pessoa ("meu", "minha") diz mais sobre a premissa teológica e política do que à vontade do sujeito que não pode ser súdito de si mesmo: a decisão do Príncipe Regente nasce do "seu desejo", mas incorpora a sede de ambas as dimensões (física e espiritual) do reino. ${ }^{30}$

29 [O autor se refere a:] SANTO TOMÁS. Summa theolog. III, 9, VIII, a.I. In: The summa theologica of Saint Thomas Aquinas. Translated by fathers of the English Dominican Province. London, Encyclopaedia Britannica, Inc. 2v, 1952; _. Lectio 2 ad Rom. XII. In: FERROL, F. M. Saavedra Fajardo y la política del Barroco. Madrid, Instituto de Estudios Políticos, 1957a.

30 O estudo de Francisco Carlos Cosentino sugere relativizar a "dicotomia" na relação entre a metrópole e a colônia: "é necessário desconstruir a natureza polarizada do relacionamento metrópole/colônia [...]. Não concebemos que o relacionamento entre o Brasil e Portugal ou qualquer outra parte constitutiva do império português possa ser caracterizado de forma simplista como sendo de exploração" (COSENTINO, 2009, p. 25-26). 
Na carta, a palavra assume conotação tanto física quanto etérea; tanto é expressão de um, quanto lei para todos; tanto é decisão de cunho administrativo, quanto sabedoria inspirada por Deus. Portanto, no âmbito terreno não haveria vontades acima daquelas comunicadas pelo representante maior da coroa. Diante da carta régia, breve em extensão, e abrangente nas intenções, a linguagem cumpre vários papéis para além do significante.

Desse modo, o documento sedimentava três intenções: 1. relembrar aos súditos (ou "vassalos") o seu lugar e procedimento ("vassalagem") na hierarquia reinol; 2. reforçar o poder real, que se submete às leis divinas e a uma legislação secular (que só a coroa seria capaz de aprovar ou revogar); 3. registrar, formalmente, que Portugal cumpria a sua parte no acordo comercial com a Inglaterra, firmado por ocasião da vinda da Coroa para o Estado do Brasil. A "tutela britânica" ganhava maior ascendência:

Ao longo do século XVIII, excluída a Holanda, a pugna pela hegemonia política e comercial desenrolou-se entre a Inglaterra e a França; os tratados de Utrecht já configuravam uma posição vantajosa para os ingleses, e os confrontos do meado do século consolidaram sua hegemonia. Através dos Tratados com Portugal (Methuen), da obtenção do asiento espanhol, e sobretudo através do intenso contrabando - o comércio interlope como era chamado - a Inglaterra penetrou fundo nos mercados coloniais ibéricos. Completava-se, assim, a tutela britânica (NOVAIS, 1989, p. 52).

Quanto ao adjetivo "real", ele aparece três vezes no documento, uma delas grafado em minúscula ("real presença"); duas, iniciado por maiúscula ("Real Fazenda"; "Real Coroa"). Teria havido um lapso, por parte de Dom João de Bragança, ao grafar a palavra pela primeira vez? Ou a diferenciação entre minúscula e maiúscula, longe de ser acidental ou arbitrária, guardaria relação com o termo lexical seguinte?

Na maneira como o documento foi escrito, percebe-se que o adjetivo "real" foi iniciado por minúscula, na passagem em que o termo posterior foi iniciado da mesma forma. A despeito dos poderes - temporal e espiritual; político e teológico - assinalados na pena empunhada pelo príncipe regente, repare-se que a sua "presença" foi registrada em minúsculo, enquanto as partes constitutivas do reino português, em maiúsculas ("Fazenda" e "Coroa").

A forma como a carta foi redigida faculta estabelecer homologias com a postura teatral do império, já transplantado para o Estado do Brasil, especialmente quando o Rio de Janeiro receber os milhares de Cortesãos, expulsando muitos dentre aqueles que moravam em residências do centro da cidade. Como salientou Alberto da Costa e Silva (2011, p. 25-26): 
Em 1808, de um dia para outro, o Rio de Janeiro transformou-se na capital portuguesa. Na cabeça do Império. Tiveram de ser recriadas, no lado americano do Atlântico, as instituições estatais metropolitanas. Ou melhor, foi necessário remontar o Estado, que tinha vindo nos navios, incompleto e aos pedaços. Transplantou-se para o Brasil o Antigo Regime, no qual só aos poucos foi abrindo brechas o pensamento antiaristocrático e liberal. E não faltou sequer que se redesenhassem no Rio de Janeiro, com o concurso de artistas franceses imigrados, as representações do teatro do poder, na aclamação de d. João VI e na aclamação e coração de d. Pedro I.

Outra palavra recorrente é "vontade". Dentre as eventuais especulações que possamos fazer, parece que a "vontade real" - misto de desejo humano e desígnio celestial, sujeitava-se, antes de tudo, ao paralelismo ordenado pela ortografia e gramática de outrora. Por aí também se repara que o poder do soberano, a chancela da mitra e os acordos comerciais submetiam-se à forma escrita. Não deixava de ser uma espécie de vassalagem do poder real e das instituições da Coroa ao providencial manto da linguagem.

\section{Recapitulação}

Realizada na manhã de 29 de novembro de 1807, a "transferência", "transmigração" ou "fuga" da Corte portuguesa para o Brasil foi precedida por uma série de acordos desvantajosos, comercial, política e economicamente para Portugal, em que o reino de Bragança era considerado um aliado comercial para os ingleses; e um entreposto inimigo, por parte dos franceses.

Como se sabe, o "episódio" começou bem antes. Provavelmente possa se considerar os eventos de fevereiro de 1793, quando a França declarou guerra à Inglaterra. Sete meses depois, os britânicos assinariam novo acordo com os portugueses, em que estes se comprometeriam a colaborar com os ingleses contra os franceses.

Desde então, embora firmasse o tratado decisivo com os britânicos, Portugal "hesitou em obedecer ao tratado inglês de 1793" (MANCHESTER, 1973, p. 61). O reino nunca esteve tão instável, daí parecer simbólica a demência de Dona Maria e o caráter tergiversador de seu filho, o Príncipe Regente Dom João.

Apesar das medidas, adotadas para francês ver, implementadas em 1796 (os portos foram considerados livres e a neutralidade portuguesa reafirmada), o acordo oficial entre Dom Antônio d'Araújo e Azevedo com o francês Tayllerand - que pressupunha o fechamento dos portos aos ingleses, não foi implementado. As peças se moviam. Do lado inglês, Lorde Greenville se interpôs e forçou o reino de Bragança a cancelar a negociação com a França. 
A situação de Portugal era comparável à de uma peteca, atirada entre dois jogadores poderosos e que, em um lance mais potente, poderia não só vencer a partida, mas sacrificar o reino de Bragança na jogada. Em 1801, a saúde do comércio inglês, somada à posição comercialmente estratégica de Portugal levaram a novas ingerências da França.

Dois anos depois, o então Príncipe Regente, Dom João de Bragança, reafirmava a posição de neutralidade do reino, em meio às disputas entre França e Inglaterra. Em 1806, Tayllerand comunicou aos ingleses que o império napoleônico se aproximava, nada amistosamente, de Portugal.

Àquela altura, dois grupos alternavam estratégias no Conselho de Estado de Dom João: um, tendente à França, liderado por Antonio d'Araújo Azevedo; outro, sob a condução de Rodrigo de Sousa Coutinho, a defender o (re)alinhamento com os ingleses. A "neutralidade", irradiada em reuniões e documentos da época, era uma palavra vazia de sentido, para dizê-lo de modo elegante. Na carta de 28 de janeiro de 1808, a ênfase na "real vontade" de Dom João de Bragança leva a suspeitar justamente do contrário.

\section{Referências}

AGUIAR, P. de. A Abertura dos Portos do Brasil: Cairu e os ingleses. Salvador: Câmara Municipal, 1960.

ALEXANDRE, V. A carta régia de 1808 e os tratados de 1810. In: OLIVEIRA, L. V. de; RICUPERO, R. (Orgs.). A Abertura dos Portos. São Paulo: Senac, 2007. p. 100-121.

AMEAL, J. História de Portugal. 2. ed. Porto: Livraria Tavares Martins, 1942.

ARRUDA, J. J. de. Uma colônia entre dois impérios: a abertura dos portos brasileiros (1800 - 1808). Bauru: Edusc, 2008.

COSENTINO, F. C. C. Governadores gerais do Estado do Brasil (séculos XVI- XVII): ofício, regimentos, governação e trajetórias. São Paulo: Annablume; Belo Horizonte: Fapemig, 2009.

COSTA E SILVA, A. da. As marcas do período. In: COSTA E SILVA, A. da. (Coord.). Crise Colonial e Independência (1808 - 1830). Rio de Janeiro: Objetiva, 2011. p. 23-33.

DIAS, E. S. de A. C. A ida da corte para o Brasil nos documentos do Arquivo Histórico Ultramarino. In: CARDOSO, J. L.; MONTEIRO, N. G.; SERRÃO, J. V. (Orgs.). Portugal, Brasil e a Europa napoleônica. Lisboa: ICS, 2010. p. 553-568. 
- | O léxico real

DOM João [Príncipe Regente]. Carta ao Conde da Ponte. Província da Bahia, 1808. Disponível em: <http://objdigital.bn.br/acervo digital/div manuscritos/mss1157496/ mss1157496.pdf>. Acesso em: 10 mar. 2018.

ELIAS, N. A sociedade de Corte: investigação sobre a sociologia da realeza e da aristocracia de Corte. Tradução de Pedro Süssekind. Rio de Janeiro: Zahar, 2001.

FISHER, H. E. De Methuen a Pombal. Tradução de Joaquim Duarte Peixoto. Lisboa: Gradiva, 1984.

FLEUISS, M. História administrativa do Brasil. 2. ed. São Paulo: Melhoramentos, 1925.

FRANÇA, E. D. Portugal na época da restauração. São Paulo: Hucitec, 1997.

HANSEN, J. A. Positivo/natural: sátira barroca e anatomia política. Revista Estudos Avançados [online], USP, São Paulo, v. 3, n. 6, p. 64-88, 1989.

KANTOROWICZ, E. The king's two bodies: a study in mediavel political theology. Princeton: Princeton University Press, 1997.

MANCHESTER, A. K. Preeminência inglesa no Brasil. Tradução de Janaína Amado. São Paulo: Brasiliense, 1973.

MARTINS FILHO, E. O Conselho de Estado Português e a transmigração da família real em 1807. Rio de Janeiro: GB/Ministério da Justiça, 1968.

MELLO, E. C. de. Um imenso Portugal: história e historiografia. São Paulo: Editora 34, 2002.

MENDONÇA, M. C. de. D. João VI e o Império no Brasil: a independência e a missão Rio Maior. Rio de Janeiro: Biblioteca Reprográfica Xerox, 1984.

MOTA, C. G. Da ordem imperial pombalina à fundação do Império brasileiro (1750-1831): o significado da Abertura dos Portos (1808). In: OLIVEIRA, L. V. de; RICUPERO, R. (Orgs.). A Abertura dos Portos. São Paulo: Senac, 2007. p. 60-99.

NORTON, L. A Corte de Portugal no Brasil. 3. ed. São Paulo: Companhia Editoria Nacional, 2008. 
NOVAIS, F. Portugal e Brasil na crise do antigo sistema colonial (1777-1808). 5. ed. São Paulo: Hucitec, 1989.

OLIVEIRA LIMA. Dom João VI no Brasil. $1^{\circ}$ volume. Rio de Janeiro: Tipografia do Comércio, 1908.

RICUPERO, R. O Brasil no mundo. In: COSTA E SILVA, A. da. (Coord.). Crise colonial e independência - 1808-1830. Rio de Janeiro: Objetiva, 2011. p. 115-159.

SANTOS, M. N. dos. O império na ponta da pena: cartas e regimentos dos governadoresgerais do Brasil. Revista Tempo (UFF), Rio de Janeiro, n. 27, p. 117-133, 2009.

SARAIVA, J. H. História concisa de Portugal. 23. ed. Mem Martins: Europa-América, 2005.

SILVA, M. B. N. da. "A Corte no Rio de Janeiro: o perigo francês, o perigo espanhol e o poderio inglês". In: CARDOSO, J. L.; MONTEIRO, N. G.; SERRÃO, J. V. (Orgs.). Portugal, Brasil e a Europa napoleônica. Lisboa: ICS, 2010. p. 297-322.

SODRÉ, N. W. As razões da independência. 2. ed. Rio de Janeiro: Civilização Brasileira, 1969.

SOUZA, M. E. de C. Ouvidores de Comarcas de Minas no século XVIII. São Paulo: Alameda, 2016.

COMO CITAR ESTE ARTIGO: CHAUVIN, Jean Pierre. O léxico real. Revista do GEL, v. 15, n. 2, p. 33-49, 2018. Disponível em: https://revistadogel.gel.org.br/

DOI: http://dx.doi.org/10.21165/gel.v15i2.2108

Submetido em: 10/04/2018 | Aceito em: 07/09/2018 